\title{
ARTICLES
}

Submitted 01.20.2017. Approved 09.22.2017

Evaluated through a double-blind review process. Guest Scientific Editor: Reinaldo Fagundes dos Santos

Original version

DOI: http://dx.doi.org/10.1590/So034-759020180202

\section{DISMISSAL: IMPORTANT CRITERIA IN MANAGERIAL DECISION-MAKING}

\author{
Demissão: Critérios importantes na tomada de decisão dos gestores \\ Dimisión: Criterios importantes en la toma de decisiones de los gestores
}

\begin{abstract}
Knowledge about dismissal decision-making, particularly concerning the criteria used by managers in choosing who will be dismissed and why, is scarce. Considering the implications of such decisions for organizations and society, in this paper, we identify the seven most frequently used criteria in dismissal decisions and examine their importance for managers. We collected data through a survey among 385 managers and used the rational ranking and the multicriteria Analytic Hierarchy Process (AHP) to analyze them. The results show that commitment, performance records, and trust have the greatest impact on the dismissal decision, whereas interpersonal relationship, growth potential, and professional experience are considered secondary criteria. These results contribute to extending our knowledge about dismissal decisions and showing the most relevant criteria in these choices and the relevance assigned to each of the criteria so that greater transparency can be achieved.
\end{abstract}

KEYWORDS | Decision-making, dismissal, dismissal criteria, human resources, analytic hierarchy process.

\section{RESUMO}

O conhecimento sobre a tomada de decisões de demissão é escasso, em particular sobre os critérios que os gestores utilizam para a escolha de quem será demitido e por quê. Considerando as implicações desse tipo de decisão para as organizações e a sociedade, neste artigo, identificamos os sete critérios mais utilizados nas decisões de demissão e sua importância para os gestores. Os dados foram coletados por meio de um survey com 385 gestores e analisados com base no ranking racional e no método multicritérios Análise Hierárquica do Processo (Analytic Hierarchy Process [AHP]). Os resultados mostraram que o compromisso, o histórico de desempenho e a confiança têm maior impacto na decisão de demissão, enquanto a relação interpessoal, o potencial de crescimento e a experiência profissional são considerados critérios secundários. Esses resultados contribuem para ampliar o conhecimento sobre decisões de demissão e para dar mais transparência a essas decisões, mostrando os critérios que mais influenciam essa escolha, bem como a relevância atribuída a cada um deles.

PALAVRAS-CHAVE / Processo decisório, demissão, critérios de demissão, recursos humanos, análise hierárquica do processo.

karinaroglio@gmail.com

ORCID: 0000-0002-5256-8330

\section{GUSTAVO ABIB ${ }^{2}$}

gustavo.abib@gmail.com

ORCID: 0000-0002-8768-9669

${ }^{1}$ Universidade de São

Paulo, Faculdade de

Economia, Administração e

Contabilidade,São Paulo, SP,

Brazil

${ }^{2}$ Universidade Federal do

Paraná, Programa de Pós-

Graduação em Administração, Curitiba, PR, Brazil

\section{RESUMEN}

El conocimiento sobre la toma de decisiones de despido es escaso, en particular en lo que se refiere a los criterios utilizados por los gestores para elegir a quién despedir y por qué. Considerando las implicaciones de este tipo de decisión para las organizaciones y para la sociedad, en este artículo identificamos los siete criterios más utilizados en las decisiones de despido y su importancia para los gestores que toman estas decisiones. Recopilamos datos en una encuesta a 385 gestores y usamos el ranking racional y el método multicriterio Proceso Analítico Jerárquico (Analytic Hierarchy Process [AHP]) para analizarlos. Los resultados mostraron que el compromiso, los registros de desempeño y la confianza tienen mayor impacto en la decisión de despido, mientras que la relación interpersonal, el potencial de crecimiento y la experiencia profesional se consideran criterios secundarios. Estos resultados contribuyen a ampliar el conocimiento sobre las decisiones de despido y a dar mayor transparencia a dichas decisiones, al mostrar los criterios que más influencian la elección, así como la relevancia asignada a cada uno de dichos criterios.

PALABRAS CLAVE I Toma de decisiones, despido, criterios de despido, recursos humanos, proceso analítico jerárquico. 


\section{INTRODUCTION}

Managers and human resource professionals are regularly involved in employee appointment, appraisal, training, compensation, promotion, and dismissal as part of their normal functions (Armstrong \&Taylor, 2014).

Most literature on human resource management focuses on the criteria, techniques, and methods about the processes of recruitment and selection, development programming, promotion, payment, and performance appraisal (Ulrich, Younger, \& Brockbank, 2008). However, the literature on contract termination issues, succession, and dismissal is scarce, and knowledge concerning the reasons why managers make dismissal decisions is limited. Thus, a gap exists in the research about issues of how individuals are replaced and what leads to their being dismissed (Hilger, Mankel, \& Richter, 2013), in addition to the circumstances prior to dismissals (McDonald, Waterhouse, \& Kellner, 2008).

In a decision-making process, managers must evaluate the alternatives available and choose one option over others based on specific criteria (Mintzberg, Raisinghani, \& Theoret, 1976; Nutt, 2011; Simon, 1997). This study identifies the hierarchy of criteria in dismissal decision-making from a managerial perspective. Based on the criteria presented in the literature, we identify those deemed the most relevant by managers during dismissal decision-making.

This study contributes to encourage research in the field of dismissal, and is justified by the necessity to understand the managers' cognitive processes during this kind of decisionmaking so that the dismissal process can be more transparent.

The rest of the paper is organized as follows. The second section covers the literature on dismissal and criteria used in the process. The third section explains the research method and the results. The last section summarizes the conclusions and limitations, as well as identifies future research agenda.

\section{DISMISSAL}

Constant changes in markets, globalization, introduction of advanced technologies, increased competitiveness, mergers and acquisitions, and new working systems have made the management of surplus employees an important activity of the human resource management department (Bratton \& Gold, 2012).

The process of dismissal, compared to other decision processes, involves substantial efforts, and despite being a mandatory role assigned to managers, is a distressing activity. However, as organizations are forced to reduce the size of their labor force or restructure their staff teams, dismissal has become a frequent activity in strategic human resource management, and although the dismissal decision-making process is specific to each organization, it is inherent to all types of companies.

Dismissal consists of discharging an employee from the organization, that is, terminating the individual from work and from the performance of duties. Ending the labor contract extends beyond the individual interests of the parties involved and reflects the social dimension, especially in organizational restructuring due to downsizing (Tylcsak, 1991).

Williams and Livingstone (1994) state that it is necessary to analyze the reasons and the criteria for dismissal considering the relevant costs as dismissing an employee also involves expenses, particularly to promote new recruitment, selection, and training.

Dismissal decision-making research includes studies on the practices and strategies in restructuring processes and downsizing (Caldas, 2000; Campion, Guerrero, \& Posthuma, 2011; Freitas, 2006; Giniger, Dispenzieri, \& Eisenberg, 1983; Harcourt, Hannay, \& Lam, 2013; Iverson \& Zatzick, 2011; Juhdi, Pa'wan, Hansaram, Kaur, \& Othman, 2011; McDonald et al., 2008; Østhus \& Mastekaasa, 2010; Shah, 2000; Tonelli, 2000; Tsai \& Yen, 2008; Tylcsak, 1991; Tzafrir \& Eitam-Meilik, 2005). Works on the succession or removal of top executives and chief executive officers (CEOs) include those by Crossland and Chen (2013), Ertugrul and Krishnan (2011), Goldman (2011), Hilger et al. (2013), Ohana and Meyer (2010), and Wiersema (2002). In these studies, the dismissal process has been analyzed predominantly from the employee's perspective. We did not find studies on the managers' viewpoint.

For dismissal, some criteria are applied to decide who will be dismissed or whether option will be pursued (Hilger et al., 2013). In the next section, these criteria and how they are hierarchized in the dismissal process are discussed.

\section{Dismissal criteria}

Dismissal decision-making involves planning and selecting from among choices-which are often sensitive-, besides time. The choices are always based on criteria, that is, who will be dismissed and who is vested with the authority to dismiss (Tylcsak, 1991). Moreover, choices are made from a limited range of possibilities (Simon, 1997). Sometimes, they are based on politics and power relations (Child, Elbanna, \& Rodrigues, 2010).

According to Shah (2000), companies opt for the dismissal process mainly to maintain or increase their levels of competitive advantage and to respond to technological changes; that is, companies do not adopt this practice only when they 
face declining performance. Other reasons for dismissals are harassment (pregnancy, incapacity, gender, age, appearance, health, race, personal issues), bullying (sexual, verbal, physical contact, or persecution without specific reasons), discrimination, unethical behavior, misappropriation, misconduct, fraud, personal situation, operational reasons, violation of the psychological contract, alteration to job contracts, complaints over salary, low performance, lack of commitment, problems in interpersonal relationships (misunderstandings between managers and employees or CEOs and investors), limited professional experience and growth potential (Campion et al., 2011; Giniger et al., 1983;
McDonald et al., 2008; Quiñones, Ford, \& Teachout, 1995; Uppal, Mishra, \& Vohra, 2014).

The criteria are inter-related, and often the managers' motivations for dismissing workers are considered subjective. For a better understanding of the process, existing literature is reviewed to identify and categorize the main reasons/criteria used by managers in dismissal decisions. Thus, Exhibit 1 shows the most recurrent dismissal criteria in the management literature, which are personal situation, trust, commitment, professional experience, interpersonal relationships, growth potential, and performance records. These criteria are discussed in detail below.

\section{Exhibit 1. Main criteria for dismissal and their respective definitions}

\begin{tabular}{|c|c|}
\hline Criteria & Definitions \\
\hline Personal situation & $\begin{array}{l}\text { Circumstances such as diseases, damage, personal reasons, absenteeism without explanation, inability to } \\
\text { work during the required hours, relationships inside or outside wrk, friends or family issues, requests of leave } \\
\text { of absence from the employee for several reasons (McDonald et al., 2008). }\end{array}$ \\
\hline Trust & $\begin{array}{l}\text { The company's expectation that the employee will not abuse of the vulnerabilities of the company if he/she has } \\
\text { the opportunity to do so (Krishnan et al., 2006). }\end{array}$ \\
\hline Commitment & $\begin{array}{l}\text { The effort of the employees so that the organization can obtain success and the degree of adjustment between } \\
\text { the values of the employees and the values of the organization (Juhdi et al., 2011). }\end{array}$ \\
\hline Professional experience & $\begin{array}{l}\text { The amount of experience achieved in a specific occupation (McDaniel et al., 1988). Accumulation of } \\
\text { experience originating from previous work in other organizations (Uppal et al., 2014). }\end{array}$ \\
\hline Growth potential & $\begin{array}{l}\text { The previews about the future performance of the employee, i. e., about his/her development and contribution } \\
\text { in the organization (Moser \& Kraft, 2008). }\end{array}$ \\
\hline Performance records & $\begin{array}{l}\text { General issues of performance, mistakes/imprecision, inadequate attitudes, communication problems } \\
\text { (McDonald et al., 2008). }\end{array}$ \\
\hline
\end{tabular}

Although many personal situations mentioned in Exhibit 1 are employee rights, companies do covertly appropriate them during the dismissal process. This criterion also includes gender, age, educational level, and individual attributes (Stumpf \& Dawley, 1981).

Issues concerning the termination of contracts, payments, complaints over wages, salaries, and repayments of loans from employers are other reasons that have led managers to opt for dismissals (McDonald et al., 2008). Dismissals for theft, bad faith, and fraud have also been alleged. In the present study, such issues are contained in the category of trust.
Trust involves the confidence individuals have in each other. It relates to availability, competence, consistency, discretion, honesty, integrity, loyalty, transparency, promise, achievement, and receptiveness (Butler, 1991). Regardless of the organizational context, a behavior that inspires trust is the result of a series of actions taken by those involved (Tzafrir \& Dolan, 2004).

Trust is also related to ethical issues. Although Ertugrul and Krishnan (2011) do not directly mention the term trust, they attribute the involvement of CEOs in illegal or unethical activities (even when their actions do not have any negative impact on the results of the company) as being the cause for their dismissal. 
Another criterion for dismissals found in the literature is commitment. For Meyer, Bobocel, and Allen (1991), commitment is related to turnover, absenteeism, and performance at work. Strongly committed employees are less likely to leave the organization (Allen \& Meyer, 1990). Commitment can be identified by the effort that the employee expends for the organization to succeed, and it is related to the willingness to engage in the company's projects and performance at work. If employees are more committed, it can be inferred that managers would prefer to retain them in the organization; thus, they are less liable to be dismissed (Juhdi et al., 2011).

Professional experience of the employee is another criterion used for dismissal (Giniger et al., 1983; Uppal et al., 2014). Quiñones et al. (1995) consider this criterion to be one of the most important as it is also related to staff selection, training, and career development. On this criterion, Adkins (1995) states that previous professional experience is related to how and to what extent the individual will socialize within the company on the job. Based on the studies by Harcourt et al. (2013) and Kirschenbaum (1992), it is possible to consider professional experience as the amount of working years of the professional and the capacity to integrate relevant information and make competent decisions.

Interpersonal relationships are also listed as one of the relevant criteria in the dismissal process. In work environments where high performance and teamwork are required, the collaboration of an individual with the rest of the group is even more evident. In this sense, the "social skills" of the individual are relevant as they reflect his/her ability to adjust to different situations and demands, in addition to influencing the behavior of others and acting cooperatively (Tzafrir \& EitamMeilik, 2005).

This ability of knowing how to work with the group is closely linked to growth potential. For Campion et al. (2011), predicting growth potential is a commonly used practice in dismissal decision-making. However, the authors observe that the criteria for measuring this potential are subjective and that older people have fewer years of career ahead; therefore, any criteria related to the age of the candidate should be avoided in a dismissal decision. According to the authors, this aspect can be measured by the previous performance of the employee.

Kraft (1991) stresses the relevance of professional performance for the organization: without good performance by individuals, it is impossible for the company to achieve its expected productivity. Thus, in addition to making clear that employees who do not perform as expected can be dismissed, a practice used by some companies to incentivize better results from employees is to pay them based on merit and efficiency, in addition to profit sharing.

Contrary to the results found by McDonald et al. (2008), the study by Hilger et al. (2013) reveals that performance (individual or organizational) is a criterion that significantly influences the chances of dismissal of top executives. The study by Crossland and Chen (2013, p. 83) demonstrates the same trend: "A second important assumption in the literature about dismissal is that the top management board has the power to dismiss CEOs (Chief Executive Officers) with low performance."

In such cases, the CEOs can be discharged: for disagreeing with the administrative board, board of directors, or shareholders concerning the strategic objectives that the organization must follow (Ertugrul \& Krishnan, 2011); due to pressure exerted by investors to increase the company's performance (Ertugrul \& Krishnan, 2011; Wiersema, 2002); and due to the intervention of shareholders who analyze, in addition to performance, the competence of the CEO (Ertugrul \& Krishnan, 2011). Nevertheless, performance affects the dismissals of both CEOs and employees in general (Stumpf \& Dawley, 1981; Williams \& Livingstone, 1994).

\section{METHODOLOGY}

The methodological procedures adopted in this study, descriptive quantitative approach was adopted as the methodology. Considering that the purpose of the study was to identify the hierarchy of criteria for dismissal during managers' decisionmaking, we conducted a survey among managers and professionals involved in decision-making and management activities.

For this research, we adopted the analytic hierarchy process (AHP). The use of AHP method is justified in those types of decision-making which involve the selection of multiple alternatives and criteria. As a general rule, decision-makers have mutually exclusive objectives and can process information in different ways because of their previous experience and value judgments. Therefore, methods based on multiple criteria decision-making (MCDM) have emerged to facilitate situations in which more than one criterion are assessed and considered in the decision-making process (Chen, 2006).

Among MCDM methods, the AHP assesses the possible criteria involved in the decision in a faster and easier manner based on decision matrixes. Huang, Keisler, and Linkov (2011, p. 735) indicate that the AHP consists of a "systematic and scientific method capable of solving complicated and subjective problems of decision making." Thus, as a result of the application 
of mathematical methods to the variables of the research, a hierarchy is obtained. This hierarchy is considered an abstraction of the structure of the system being studied (Saaty, 2008).

A set of criteria grouped together can then be classified as the combination of pairwise comparisons among them (taken in groups of two), with eventual inconsistencies found (due to the multiplicity of pairwise comparisons among all of the criteria of the group, performed separately) being interpreted as errors of the cognitive process. Errors are typically eliminated, taking some convenient average of the results of the pairwise comparisons.

About the index of consistency of the method, Saaty (2006) states that the pairwise comparisons are obtained by directly questioning people who can or cannot be specialists but are familiar with the problem. A central point in this approach is that people are frequently inconsistent, even though the priorities must be defined, and actions must be taken concerning the inconsistency (Saaty, 2008).

Over a two-month period, the link of the 20-item questionnaire was sent by e-mail to 2,150 managers and professionals in Brazil who work in several sectors of the economy. We used two databases of professionals: one from the Brazilian Association of Human Resources (Associação Brasileira de Recursos Humanos [ABRH]) and another from the Fundação Getulio Vargas. Our target was executives/managers who had subordinates. The respondents were invited to resend the invitation to their colleagues, in the manner of a snowball sampling (Goodman, 1961). After 60 days, 385 valid answers were collected, and the respondents' profile is presented in Table 1.

Table 1. Profile of research respondents

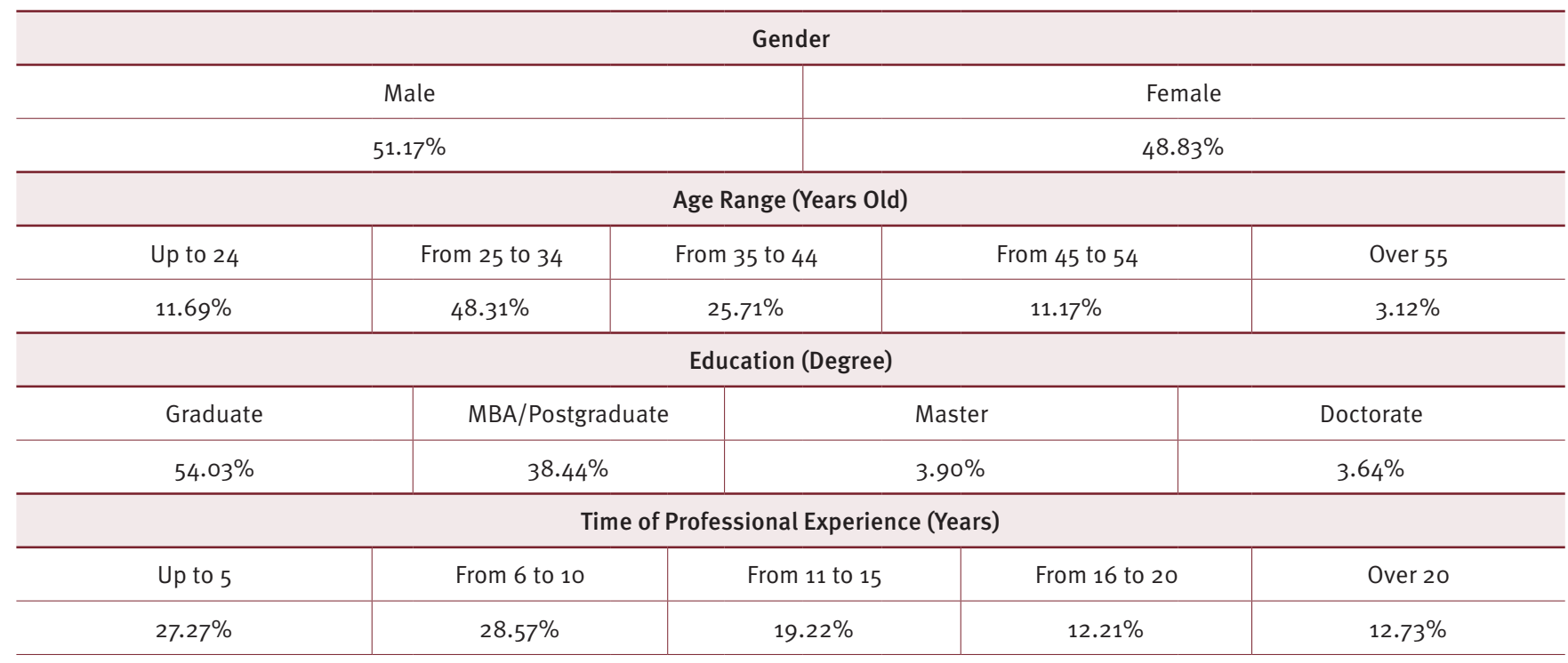

Source: Research data (385 respondents).

There is a predominant profile of male decision-makers (51.17\%), aged from 25 to 44 years old $(74.03 \%)$, with a higher education or graduate/MBA level of education ( $92.47 \%$ ), and with up to 10 years of professional experience (55.84\%).

The research instrument was subjected to a pre-test to exclude possible questions with double interpretations and improve their formulation. It was applied to a group of 26 managers, which allowed spelling out and general scale adjustments in the data-gathering instrument.

At the beginning of the questionnaire, the respondents read directions regarding the context of the research so that all of them had similar acquaintance with the dismissal situation they were evaluating. The guiding question of the research is described as follows:
You have just been hired to conduct the process of a merger of two companies that conduct business in the food industry. These companies have redundant departments-with the merger, it cameto be that, for example, 2 departments were managing the same operations. In this moment, the duplicated operations will be eliminated. Facing this situation, you will have to dismiss a group of professionals. In this research, we want to know which criteria you would use to choose the people who will be dismissed.

From this moment, the respondents were instructed to rank the seven criteria for dismissal (selected from the theory), randomly presented, according to the degree of importance that they attributed to each: (1) personal situation, (2) performance records, (3) commitment, (4) trust, (5) professional experience, (6) growth potential, and (7) interpersonal relationships. After this 
process of ranking, the next step was a pairwise comparison of the first four dismissal criteria ranked based on the AHP method.

In the first part of the instrument, the respondents listed among the seven possible criteria their order of importance in his/her evaluation during the process of dismissal. Then, the top four criteria were compared in pairs, evaluating the high or low preference by one or another. Thus, each respondent made the pairwise crossing of up to four criteria, that is, six pairwise interactions for each respondent. In this manner, we evaluated the consistency between the rational ranking and the pairwise hierarchy among the criteria. The survey form used can be accessed at https://dismissaldecisionmaking.qualtrics.

For assigning the degree of importance, a scale ranging from 1 to 9, presented in Exhibit 2, was adopted; here, 1 means that compared to each other, the criteria are given the same importance whereas 9 means that one of them is strongly preferable at the expense of the others.
Exhibit 2. The fundamental scale of absolute numbers

\begin{tabular}{c|c}
\hline Intensity of importance & Definition \\
\hline 1 & Equal Importance \\
\hline 3 & Moderate Importance \\
\hline 5 & Strong Importance \\
\hline 7 & Very strong Importance \\
\hline 9 & Extreme Importance \\
\hline
\end{tabular}

Source: Adapted from Saaty (2008). Intensities of 2,4,6 and 8 can be used to express intermediate values.

Table 2 represents four criteria chosen by each respondent. Following the methodological steps, it is possible to find the eigenvector of each criterion and, subsequently, the main eigenvector $\left(\lambda_{\text {MAX }}\right)$. Based on the main eigenvalue and the number of alternatives, we obtain the consistency ratio $\left(C R=\left(\lambda_{\operatorname{MAx}}-n\right) /\right.$ $(n-1))$, calculated according to the following formula:

\section{Table 2. Example with four main criteria from one respondent}

\begin{tabular}{|c|c|c|c|c|c|}
\hline Goal & Trust & $\begin{array}{l}\text { Interpersonal } \\
\text { relationship }\end{array}$ & Commitment & $\begin{array}{c}\text { Performance } \\
\text { records }\end{array}$ & Relative weights \\
\hline Trust & 1 & 5 & 5 & 5 & 0.6181 \\
\hline $\begin{array}{l}\text { Interpersonal } \\
\text { Relationship }\end{array}$ & 0.2 & 1 & 1 & 0.5 & 0.1069 \\
\hline \multirow[t]{2}{*}{ Performance records } & 0.2 & 2 & 1 & 1 & 0.1514 \\
\hline & 1.6 & 9 & 8 & 7.5 & \\
\hline
\end{tabular}

$$
\lambda_{\text {MAX }}=[(0.6181 \times 1.6)+(0.1069 \times 9)+(0.1236 \times 8)+(0.1514 \times 7.5)]=4.0757
$$

$$
C R=((4.0757-4) \div(4-1))=0.02523
$$

According to this method, the consistency ratio must be below 0.1. Using the main eigenvector and the number of criteria, we determined the consistency ratio. In the example of the respondent above, the ratio was 0.02523 (2). In all cases (385), the consistency value was reached.
After generating a set of weights for each alternative $\left(w_{j}\right)$, we combined the single priorities across all criteria to determine the global priority $\left(w_{i}\right)$, presented by formula (3). Transparent Choice software was used to calculate all answers and combine the total weight of the criteria.

$$
w_{i}=\sum w_{j} \times v_{j}\left(v_{j}-\text { number of observations of the criterion }\right)
$$

Normality of distribution of each criterion was verified using a one-sample Kolmogorov-Smirnov test. The results are presented in Table 3. 
Table 3. Kolmogorov-Smirnov test for one-sample

\begin{tabular}{|c|c|c|c|c|c|}
\hline Criteria & N & Average & Standard deviation & $\begin{array}{l}\text { Kolmogorov- } \\
\text { Smirnov Z }\end{array}$ & $\begin{array}{l}\text { Asymp. Sig. } \\
\text { (2Tailed) }\end{array}$ \\
\hline Trust & 301 & 0.2623 & 0.165 & 1.429 & 0.034 \\
\hline Interpersonal relationship & 219 & 0.2206 & 0.156 & 1.569 & 0.015 \\
\hline Commitment & 354 & 0.3050 & 0.154 & 1.379 & 0.045 \\
\hline Personal situation & 30 & 0.2387 & 0.210 & 0.954 & 0.323 \\
\hline Performance records & 301 & 0.2685 & 0.168 & 1.325 & 0.050 \\
\hline Growth potential & 159 & 0.2123 & 0.152 & 0.558 & 0.016 \\
\hline
\end{tabular}

Note: $\mathrm{n}=385$ respondents

The results (Table 3) show that six criteria (trust, interpersonal relationships, commitment, professional experience, performance records, and growth potential) have a normal distribution ( $95 \%$ Confidence Interval, $\sigma<0.05$ ). For the personal situation criterion, a normal distribution was not seen ( $\sigma>0.05$ ); thus, the results of this criterion are not statistically reliable and were not considered in the analysis.

\section{RESULTS}

Based on the criteria presented in Exhibit 1, the respondents made a rational classification of the criteria between the first and the seventh, in which the first consists of the criteria considered to have the highest weight in their decisions of dismissal whereas the seventh is the last criterion to be considered. From this classification, the criteria were ranked according to the results in Table 4.

Table 4. Hierarchy of dismissal criteria by rational sequencing

\begin{tabular}{c|c|c|c|c|c|c|c}
\hline & Trust & $\begin{array}{c}\text { Professional } \\
\text { experience }\end{array}$ & Commitment & $\begin{array}{c}\text { Interpersonal } \\
\text { relationship }\end{array}$ & $\begin{array}{c}\text { Personal } \\
\text { situation }\end{array}$ & $\begin{array}{c}\text { Performance } \\
\text { records }\end{array}$ & $\begin{array}{c}\text { Growth } \\
\text { potential }\end{array}$ \\
\hline $1^{\circ} \underline{0}$ & $24.94 \%$ & $9.61 \%$ & $29.35 \%$ & $5.19 \%$ & $1.30 \%$ & $25.97 \%$ & $3.64 \%$ \\
\hline $2^{\circ}$ & $23.12 \%$ & $10.13 \%$ & $31.95 \%$ & $11.17 \%$ & $1.56 \%$ & $17.14 \%$ & $4.94 \%$ \\
\hline $3^{\circ}$ & $13.77 \%$ & $11.95 \%$ & $20.78 \%$ & $19.22 \%$ & $2.08 \%$ & $18.44 \%$ & $13.77 \%$ \\
\hline $4^{\circ}$ & $16.36 \%$ & $14.03 \%$ & $9.87 \%$ & $21.30 \%$ & $2.86 \%$ & $16.62 \%$ & $18.96 \%$ \\
\hline $5^{\circ}$ & $11.95 \%$ & $22.34 \%$ & $3.12 \%$ & $15.58 \%$ & $9.35 \%$ & $27.01 \%$ \\
\hline $6^{\circ}$ & $7.53 \%$ & $23.38 \%$ & $3.38 \%$ & $19.22 \%$ & $16.36 \%$ & $8.83 \%$ & $21.30 \%$ \\
\hline $7^{0}$ & $2.34 \%$ & $8.57 \%$ & $1.56 \%$ & $8.31 \%$ & $66.49 \%$ & $2.34 \%$ & $10.39 \%$ \\
\hline
\end{tabular}

Note: $\mathrm{n}=385$ respondents

We found that trust $(61.82 \%)$, commitment $(82.08 \%)$, and performance records $(61.56 \%)$ form a group of criteria predominantly used by the respondents in their dismissal decisions, given that they are concentrated in the first, second, and third hierarchical positions.

Professional experience (59.74\%), interpersonal relationship $(56.10 \%)$, and growth potential $(67.27 \%)$ form an intermediate group as they are more frequently considered between the fourth and the sixth hierarchical criteria positions. The personal situation criterion was ranked last by $66.49 \%$ of the respondents; it represents the last criterion used by the respondents in their dismissal decision.

In addition to the rational ranking of the dismissal criteria, a cognitive hierarchy was constructed, conducting pairwise analysis based on the AHP method. Because the respondent assigns more relevance only to the first criterion, the four first criteria listed by each respondent in the rational ranking process were compared pairwise. The subsequent criteria, having a smaller impact on the perception of the respondent, would not have an impact on his/her real cognition (see Table 5). 
Table 5 . Hierarchy of dismissal criteria by cognitive sequencing (AHP)

\begin{tabular}{l|c|c|c|c|c|c|c|c}
\hline Criteria & Average & LI & LS & ME & Min & Max & StDev & Count \\
\hline Commitment & 0.3050 & 0.2915 & 0.3185 & 0.0135 & 0.0344 & 0.75 & 0.154 & 354 \\
\hline Performance records & 0.2685 & 0.2526 & 0.2844 & 0.0159 & 0.0188 & 0.6654 & 0.168 & 301 \\
\hline Trust & 0.2623 & 0.2467 & 0.2780 & 0.0156 & 0.033 & 0.7018 & 0.165 & 301 \\
\hline Personal situation & 0.2387 & 0.1757 & 0.3017 & 0.063 & 0.0279 & 0.6729 & 0.210 & 30 \\
\hline Interpersonal relationship & 0.2206 & 0.2033 & 0.2380 & 0.0173 & 0.0188 & 0.69 & 0.156 & 219 \\
\hline Growth potential & 0.2123 & 0.1925 & 0.2321 & 0.0198 & 0.0254 & 0.6683 & 0.152 & 159 \\
\hline Professional experience & 0.1592 & 0.1437 & 0.1746 & 0.0155 & 0.0301 & 0.6057 & 0.125 & 176 \\
\hline
\end{tabular}

Note: $\mathrm{n}=385$ respondents

From Table 5, it is clear that the criteria of commitment (average 0.3050), performance records (average 0.2685), and trust (average 0,2623 ) hold the highest averages among the criteria assessed. From the confidence interval of $31.85 \%$ and $29.15 \%$, we find that commitment is the most relevant criterion and holds the top hierarchical position. For the criteria of trust (given a confidence interval of $24.67 \%$ to $27.80 \%$ ) and performance records (with a confidence interval of $25.26 \%$ to $28.44 \%$, no significant difference in importance between the two is observed, and they rank second in the hierarchy of the dismissal decision.

Using a dummy variable, we verified that 205 respondents $(N=385)$, that is, $53.25 \%$, indicate these three criteria (commitment, trust, and performance records) among the four most relevant.

Interpersonal relationships and growth potential, with averages of $22.06 \%$ and $21.23 \%$, respectively, represent the third group of criteria. Considering the reliability in a normal distribution of $95 \%$, both criteria are not significantly different in the hierarchy constructed by the respondents of the research.

For the personal situation criterion, only 30 cases $(7.79 \%)$ classified it as among the four main criteria. Thus, it is clear that only few professionals recognize this criterion when deciding on dismissal. This result is also reflected in the confidence interval of this criterion, which is between $17 \%$ and $30 \%$; that is, it holds little reliability.

In a comparison of the rational and the AHP methods we verified whether the four main criteria maintained their positions even when the classification method was changed. Only 65 respondents (16.88\%) maintained the same order in the classification by both methods; 224 respondents (58.18\%) maintained two criteria with the same classification, with two criteria changing positions; and 96 respondents (24.93\%) changed the positions of all of the criteria.

AHP analysis of the criteria for dismissal was also compared according to gender, respondents' prior experience with dismissal, and professional experience. Table 6 presents the separation of the sample by gender, with 197 respondents being male (51.17\%) and 188 respondents female (48.83\%).

We believe that the personal situation criterion holds low representativeness (30 respondents) and a margin of error (ME) greater than $0.05 \%$ for both male (0.1107) and female respondents (0.0704). Therefore, despite the difference in the positioning of this criterion in the hierarchy, this result is not statistically reliable and was not considered in the analysis of this comparison.

For the male respondents, performance (29.82\%), commitment $(27.79 \%)$, and reliability $(26.43 \%)$ are considered the most relevant. For the female respondents also, these three criteria (commitment-33.25\%, reliability-26.03\%, and performance records-23.75\%) appear to have the greatest impact on their decision. Given the confidence interval of these criteria, only commitment shows a significant difference for female respondents, statistically ranking (reliability of 95\%) first.

Among the second group of criteria, interpersonal relationships, growth potential, and professional experience were identified for both males $(22.16 \%, 21.89 \%$, and $5.10 \%)$ and females (21.95\%, $20.47 \%$, and $16.79 \%)$. Although these criteria present the same hierarchical order in the comparison between genders, only professional experience shows a confidence interval of $95 \%$ for male respondents, taking the last position.

Besides gender comparison, AHP analysis of the criteria for dismissal was compared for the experience with dismissal. The respondents who had ever actively participated in at least one dismissal decision were considered. This comparative analysis is presented in Table 7. 
Table 6. Hierarchy of dismissal criteria by cognitive sequencing (AHP) with gender comparison

\begin{tabular}{|c|c|c|c|c|c|c|c|c|}
\hline \multicolumn{9}{|l|}{ Male $(\mathrm{N}=197)$} \\
\hline & Average & ME & StDev & $\mathrm{LI}$ & LS & Min & Max & Count \\
\hline Performance records & 0.2982 & 0.0240 & 0.1785 & 0.2742 & 0.3221 & 0.0339 & 0.6654 & 150 \\
\hline Personal situation & 0.2951 & 0.1107 & 0.2427 & 0.1844 & 0.4059 & 0.0309 & 0.6108 & 13 \\
\hline Commitment & 0.2779 & 0.0186 & 0.1512 & 0.2593 & 0.2965 & 0.0344 & 0.6654 & 178 \\
\hline Trust & 0.2643 & 0.0237 & 0.1787 & 0.2406 & 0.2880 & 0.0336 & 0.7018 & 154 \\
\hline Interpersonal relationship & 0.2216 & 0.0246 & 0.1617 & 0.1970 & 0.2462 & 0.0188 & 0.6900 & 117 \\
\hline Growth potential & 0.2189 & 0.0280 & 0.1568 & 0.1909 & 0.2469 & 0.0337 & 0.6683 & 85 \\
\hline Professional experience & 0.1510 & 0.0240 & 0.1394 & 0.1270 & 0.1750 & 0.0339 & 0.6057 & 91 \\
\hline \multicolumn{9}{|l|}{ Female $(\mathrm{N}=188)$} \\
\hline & Average & ME & StDev & $\mathrm{LI}$ & LS & Min & Max & Count \\
\hline Commitment & 0.3325 & 0.0189 & 0.1527 & 0.3135 & 0.3514 & 0.0391 & 0.7500 & 176 \\
\hline Trust & 0.2603 & 0.0204 & 0.1501 & 0.2399 & 0.2806 & 0.0330 & 0.6523 & 147 \\
\hline Performance records & 0.2375 & 0.0202 & 0.1516 & 0.2172 & 0.2577 & 0.0000 & 0.6326 & 152 \\
\hline Interpersonal relationship & 0.2195 & 0.0244 & 0.1501 & 0.1951 & 0.2439 & 0.0280 & 0.6644 & 102 \\
\hline Growth potential & 0.2047 & 0.0281 & 0.1469 & 0.1766 & 0.2327 & 0.0254 & 0.6181 & 74 \\
\hline Personal situation & 0.1955 & 0.0704 & 0.1764 & 0.1252 & 0.2659 & 0.0279 & 0.6729 & 17 \\
\hline Professional experience & 0.1679 & 0.0191 & 0.1072 & 0.1488 & 0.1870 & 0.0301 & 0.4757 & 85 \\
\hline
\end{tabular}

Note: $\mathrm{n}=385$ respondents

Table 7. Hierarchy of dismissal criteria by cognitive sequencing (AHP) with comparison of experience in dismissal

Dismissal experience $(\mathrm{N}=230)$

\begin{tabular}{|c|c|c|c|c|c|c|c|c|}
\hline & Average & ME & StDev & $\mathrm{LI}$ & LS & Min & Max & Count \\
\hline Commitment & 0.2955 & 0.0174 & 0.1536 & 0.2780 & 0.3129 & 0.0344 & 0.6729 & 210 \\
\hline Performance records & 0.2834 & 0.0217 & 0.1747 & 0.2617 & 0.3050 & 0.0188 & 0.6644 & 176 \\
\hline Trust & 0.2759 & 0.0200 & 0.1669 & 0.2558 & 0.2959 & 0.0336 & 0.7018 & 188 \\
\hline Interpersonal relationship & 0.2251 & 0.0227 & 0.1611 & 0.2024 & 0.2478 & 0.0280 & 0.6900 & 136 \\
\hline Personal situation & 0.1888 & 0.0623 & 0.1693 & 0.1265 & 0.2510 & 0.0279 & 0.6108 & 20 \\
\hline Growth potential & 0.1820 & 0.0229 & 0.1351 & 0.1590 & 0.2049 & 0.0254 & 0.6057 & 94 \\
\hline Professional experience & 0.1534 & 0.0199 & 0.1183 & 0.1335 & 0.1732 & 0.0301 & 0.5853 & 96 \\
\hline \multicolumn{9}{|c|}{ Without dismissal experience $(\mathrm{N}=155)$} \\
\hline & Average & ME & StDev & $\mathrm{LI}$ & LS & Min & Max & Count \\
\hline Personal situation & 0.3385 & 0.1325 & 0.2547 & 0.2061 & 0.4710 & 0.0339 & 0.6729 & 10 \\
\hline Commitment & 0.3190 & 0.0212 & 0.1544 & 0.2978 & 0.3401 & 0.0396 & 0.7500 & 144 \\
\hline Growth potential & 0.2561 & 0.0336 & 0.1648 & 0.2225 & 0.2897 & 0.0339 & 0.6683 & 65 \\
\hline Performance records & 0.2476 & 0.0228 & 0.1552 & 0.2248 & 0.2704 & 0.0266 & 0.6654 & 125 \\
\hline Trust & 0.2398 & 0.0248 & 0.1601 & 0.2150 & 0.2646 & 0.0330 & 0.6644 & 113 \\
\hline Interpersonal relationship & 0.2133 & 0.0267 & 0.1479 & 0.1866 & 0.2400 & 0.0188 & 0.6644 & 83 \\
\hline Professional experience & 0.1661 & 0.0244 & 0.1327 & 0.1417 & 0.1905 & 0.0339 & 0.6057 & 80 \\
\hline
\end{tabular}

Note: $\mathrm{n}=385$ respondents 
The personal situation criterion was ignored, due to its low representativeness $(7.79 \%)$ and an ME greater than 0.05 (0.06 and 0.13).

For the 230 respondents with experience with dismissal, commitment (29.55\%), performance records (28.34\%), and reliability $(27.59 \%)$ are the most important. Considering the reliability of $95 \%$ on a normal distribution curve, there is no significant difference among them.

For this same group of respondents, it was observed that interpersonal relationships, growth potential, and professional experience showed averages of $22.51 \%, 18.20 \%$, and $15.34 \%$, respectively; therefore, they form a second group of criteria. Although interpersonal relationships (limit inferior-LI-20.24\%) and growth potential ( $\mathrm{LI}-20.49 \%)$ criteria present a merely tangential approximation, they cannot be considered significantly different, given the sample size.

For the 155 respondents without experience with dismissal, commitment carried the highest weight in their cognitive simulation, and it presented an average of $31.90 \%$. Given a confidence interval of $29.78 \%$ to $34.01 \%$, it is significantly different from the other criteria.

Continuing with the analysis of the respondents without experience with dismissal, we found that growth potential (25.61\%), performance records (24.76\%), reliability (23.98\%), interpersonal relationships (21.33\%), and professional experience $(16,615)$ form a second group in the hierarchy of criteria. In contrast to the previous analyses, the growth potential criterion holds a higher average value than that of reliability and performance records; considering their confidence intervals, they are not significantly different and, therefore, are part of the same group of criteria.

We also compare the results by dividing the sample group into respondents with more than ten years of professional experience $(N=170)$ and those with less than ten years of professional experience $(N=215)$; the results are presented in Table 8.

Table 8. Hierarchy of dismissal criteria by cognitive sequencing (AHP) with comparison of professional experience

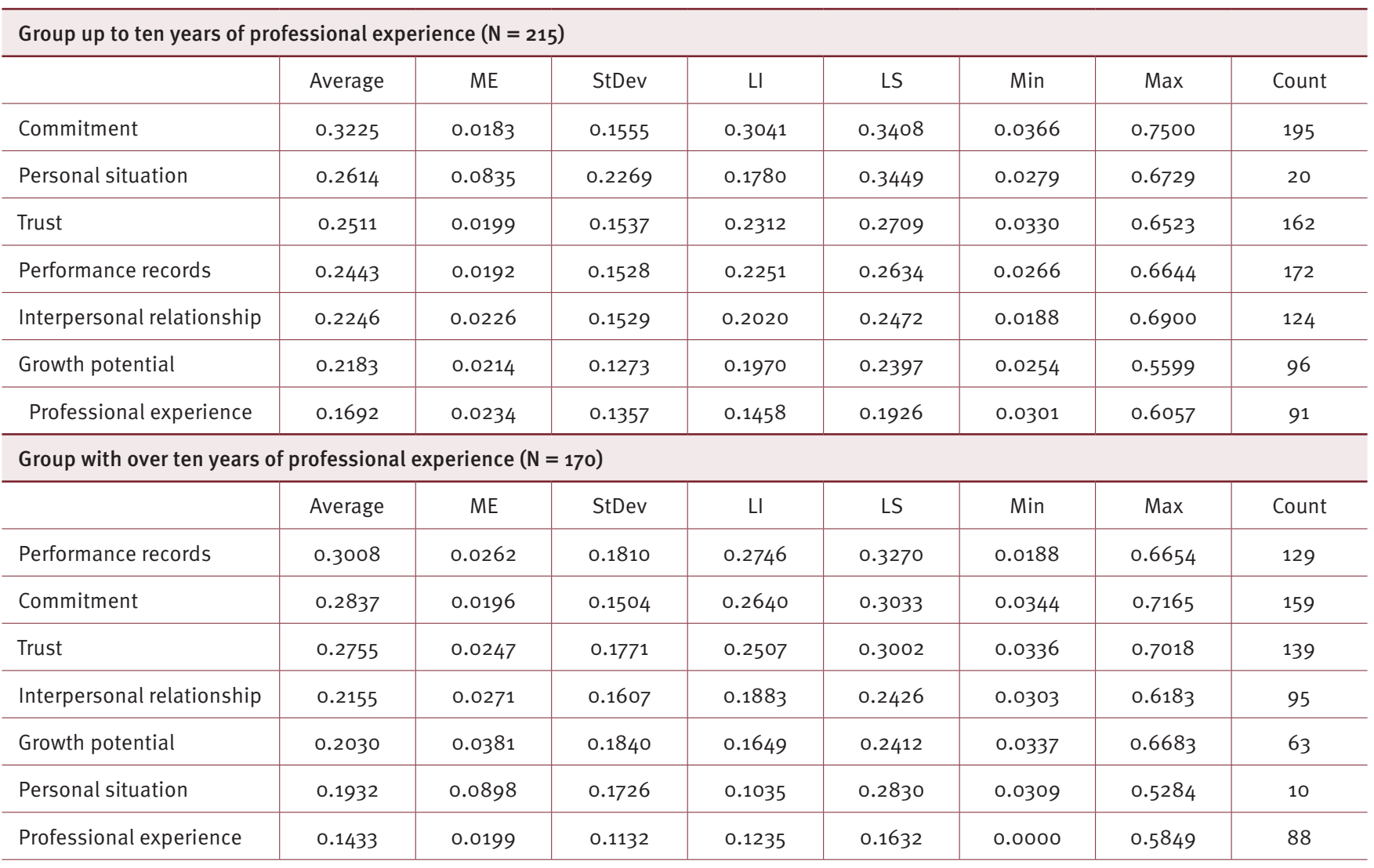

Note: $\mathrm{n}=385$ respondents

Just as in the previous analyses, the personal situation criterion is ignored due to its low representativeness (30 respondents) and an ME greater than 0.05 ( 0.08 and 0.09 approximately) as seen in Table 7. 
For the 215 respondents with up to ten years of experience, who are considered less experienced in this study, commitment holds the highest average (32.25\%), and considering the confidence interval of $30.41 \%$ to $34.08 \%$, it is significantly different from the others and ranks first in the hierarchy of criteria.

The next criteria that the less experienced respondents consider are reliability, performance records, interpersonal relationships, and growth potential with the following average probabilities of $25.11 \%, 24.43 \%, 22.46 \%$ and $21.83 \%$, respectively. Given the confidence interval of each of these criteria, as shown in Table 7, they cannot be considered to occupy significantly different positions, and hierarchically, they would be in a second group of criteria. The professional experience criterion held an average of 16.92 among the less experienced respondents, and considering its confidence interval, it ranks last in this sample group.

In the analysis of the respondents with more than ten years of experience, it was observed that performance records (30.08\%), commitment (28.37\%), and reliability (27.55\%) are the criteria most important in the dismissal decision. Although these criteria do not show significant differences among themselves, considering the confidence intervals of each, they appear to be significantly different from the others and, therefore form the group of criteria that the more experienced managers consider.

Interpersonal relationships and growth potential form a second group of criteria with averages of $21.55 \%$ and $20.30 \%$, respectively. Observing the confidence intervals, they appear to be situated between the group containing the most important criteria and the professional experience criterion, which ranks lowest in the hierarchy with an average of $14.33 \%$.

\section{DISCUSSION}

Considering the results presented in this paper, commitment, performance records, and trust appear to be the criteria with the greatest impact on the dismissal decision by the sample group of the survey $(N=385)$. In some sampling separations, commitment appeared to be the most important criterion for male respondents and those with less than ten years of professional experience. This result agrees with the findings of Allen and Meyer (1990), who argued that when there is commitment, the employee has greater chances of staying in the organization; that is, it is an important criterion to be assessed in the process of dismissal.

For the criterion of performance records, also called accomplishment, studies by Hilger et al. (2013) and Crossland and Chen (2013) have established that it significantly influences the dismissal of top executives; it also demonstrated that this criterion was included in the group of criteria which had the greatest impact on the decision. Furthermore, as noted by Stumpf and Dawley (1981) and Williams and Livingstone (1994), accomplishment is not only evaluated for top management jobs but also for all hierarchical levels, which this study has also confirmed, through a hierarchy of criteria applicable to dismissal in a group of managerial and operational activities.

Interpersonal relationships, growth potential, and professional experience form a group of secondary criteria; that is, they are statistically considered by the respondents to be of lower relevance than the criteria of the first group. In some comparisons among sample groups, the professional experience criterion can significantly differ from the others and rank last, as shown by the male respondents and those with more than ten years of experience.

Professional experience, as noted by Quiñones et al. (1995) and Adkins (1995), is a relevant criterion in the process of recruitment as it is related to possible career development, socialization of the individual, and his/her performance based on the experience. Nevertheless, it is not so important during the dismissal process. According to Watrous, Huffman, and Pritchard (2006), professional experience is related to the performance of the professional in the process of dismissal; comparing and hierarchizing the criteria of performance and experience, what prevails is the current performance.

For the criteria of growth potential and interpersonal relationships, which are connected to each other according to Moser and Kraft (2008), they are also close in the hierarchy of criteria for dismissal. For Morgeson, Reider, and Campion (2005), interpersonal relationships, that is, the social abilities of the employee, are important to ensure the development and growth of the working group, and therefore, in the dismissal decision, performance will be more important than interpersonal relationships. Similarly, growth potential, according to Campion et al. (2011), is considered in the dismissal decision-making; however, it does not have a great impact on the decision, appearing in the intermediate group of criteria for dismissal.

The personal situation criterion, due to its low representativeness in the sample studied $7.79 \%$ of the respondents), did not present reliable intervals and was not considered in the comparative analyses. However, in the study by McDonald et al. (2008), even though personal situation, which is linked to personal circumstances, is noted as being one of the most evaluated criteria during the process of dismissal, several other reasons were also indicated such as inability to work (which in this study matches the criteria of accomplishment), relationships inside or outside of work situation (addressed 
here as interpersonal relationships), and trust. Therefore, considering the clear and specific definition of the criteria for this study, personal situation, which concerns the situation of the employee outside of the workplace (health, family, etc.), is scarcely evaluated in the dismissal decision.

The dismissal criteria were also analyzed through sample comparison (gender, experience with dismissal, and professional experience), and no significant differences in the between-groups analysis were found. Thus, further research can deepen the analysis of the impact of the decision-maker's background on the dismissal decision and its criteria.

\section{CONCLUSION}

In this study, we sought to identify the hierarchy of criteria in dismissal decision-making from the perspective of managers. Based on criteria identified in the literature review, those considered to be the most relevant to managers when making dismissal decisions were identified through field research. The data analysis of 385 questionnaires supported the hierarchy of criteria and comparison of the cognitive styles by using the MCDM AHP.

In summary, the data indicated that the criteria of commitment, performance records, and trust have the greatest impact on the dismissal decision whereas the criteria of interpersonal relationships, growth potential, and professional experience form a group of secondary criteria. The personal situation was considered to be a criterion with little relevance in dismissal decisions in the opinion of the managers surveyed.

One contribution of these results is the expansion of knowledge about dismissal decisions, which, as noted above, is a scarce subject in the strategic human resource management literature, despite its growing relevance as an organizational practice. Another contribution is the possibility of making the dismissal decisions more transparent as the criteria used for the choice are learned, in addition to the relevance assigned to each. The data of the sample studied also allow reflections on the processes of performance appraisal in organizations as commitment was considered the most important criterion for dismissal by the managers surveyed.

About the method used for data analysis, this study makes contributions to comparing and understanding the cognitive styles and profile of the respondents based on the AHP method, which allows managers to build scenarios to help in decisionmaking and, therefore, make better decisions. While choosing this method, we wanted to overcome the limitation that people do not always answer exactly how they would act when they had to decide and are not able to evaluate all of the criteria in a hierarchical form. For this reason, we chose the AHP and pairwise comparison, which enabled a more transparent analysis regarding the hierarchy of the dismissal criteria identified.

Another contribution is the application of the AHP method to large samples as studies that have used this method so far had few respondents: two, three, or up to ten people at most. In our study, the method was used to delineate the profile and to compare answers in a population of 385 respondents, showing the viability of its application in large samples.

One limitation of the study was the definition of the criteria for dismissal, given that they were specified through the literature review, and there are few papers published on this subject. We acknowledge other criteria for dismissal can also be categorized and hierarchized, and further qualitative research to understand dismissal decision-making or more experiments for identification or validation of these criteria are recommended.

As an agenda for future research, by recognizing that the backgrounds of managers-such as their age, experience, background, values and other personal characteristics-can influence the rationalization and the process of ranking the criteria for dismissal, assessing these characteristics when delineating the profile of the managers and performing a comparison of the hierarchy of criteria based on these characteristics are recommended. Another possibility for future research is comparison among countries as the order of the criteria can also be linked to the cultural aspects of each region, and a cross-country study can reveal differences in the hierarchy of criteria.

\section{REFERENCES}

Adkins, C. L. (1995). Previous work experience and organizational socialization: A longitudinal examination. Academy of Management Journal, 38(3), 839-862.

Allen, N. J., \& Meyer, J. P. (1990). The measurement and antecedents of affective, continuance and normative commitment to the organization. Journal of Occupational and Organizational Psychology, 63(1), 1-18. doi:10.1111/j.2044-8325.1990.tboo506.x

Armstrong, M., \& Taylor, S. (2014). Armstrong's handbook of human resource management practice. London, UK: Kogan Page Publishers.

Bratton, J., \& Gold, J. (2012). Human resource management: Theory and practice. Basingstoke, UK: Palgrave Macmillan.

Butler, J. K. (1991). Toward understanding and measuring conditions of trust: Evolution of a conditions of trust inventory. Journal of Manage ment, $17(3), 643-663$. doi:10.1177/014920639101700307 
Caldas, M. P. (2000). Enxugamento de pessoal no Brasil: Podem-se atenuar seus efeitos em empresa e indivíduo? RAE-Revista de Administração de Empresas, 40(1), 29-41. doi:10.1590/Soo3475902000000100004

Campion, M. A., Guerrero, L., \& Posthuma, R. (2011). Reasonable human resource practices for making employee downsizing decisions. Organizational Dynamics, 40(3), 174-180. doi:10.1016/j.orgdyn.2011.04.004

Chen, C. F. (2006). Applying the analytical hierarchy process (AHP) approach to convention site selection. Journal of Travel Research, 45(2), 167-174. doi:10.1177/0047287506291593

Child, J., Elbanna, S., \& Rodrigues, S. (2010). The political aspects of strategic decision making. In P. C. Nutt and D. Wilson (Eds.), The Handbook of Decision Making(pp. 105-137). Chichester, UK: Wiley.

Crossland, C., \& Chen, G. (2013). Executive accountability around the world: Sources of cross-national variation in firm performanceCEO dismissal sensitivity. Strategic Organization, 11(1), 78-109. doi:10.1177/1476127012460946

Ertugrul, M., \& Krishnan, K. (2011). Can CEO dismissals be proactive? Journal of Corporate Finance, 17(1), 134-151. doi:10.1016/j.jcorpfin.2010.09.008

Freitas, M. E. D. (2006). Por uma ética na demissão? RAE-Revista de Administração de Empresas, 46(1), 102-106. doi:10.1590/So03475902006000100007

Giniger, S., Dispenzieri, A., \& Eisenberg, J. (1983). Age, experience, and performance on speed and skill jobs in an applied setting. Journal of Applied Psychology, 68(3), 469-475. doi:10.1037/0021. 9010.68.3.469

Goldman, A. (2011). Demagogue to dialogue: An alternative to toxic leadership in corporate downsizings. Organizational Dynamics, 40(3), 235-241. doi:10.1016/j.orgdyn.2011.04.011

Goodman, L. A. (1961). Snowball sampling. The Annals of Mathematical Statistics, $32(1), 148-170$.

Harcourt, M., Hannay, M., \& Lam, H. (2013). Distributive justice, employment-at-will and just-cause dismissal. Journal of Business Ethics, 115(2), 311-325. doi:10.1007/s10551-012-1400-9

Hilger, S., Mankel, S., \& Richter, A. (2013). The use and effectiveness of top executive dismissal. The Leadership Quarterly, 24(1), 9-28. doi:10.1016/j.leaqua.2012.07.001

Huang, I. B., Keisler, J., \& Linkov, I. (2011). Multi-criteria decision analysis in environmental sciences: Ten years of applications and trends. Science of the Total Environment, 409(19), 3578-3594. doi:10.1016/j. scitotenv.2011.06.022

Iverson, R. D., \& Zatzick, C. D. (2011). The effects of downsizing on labor productivity: The value of showing consideration for employees' morale and welfare in high-performance work systems. Human Resource Management, 50(1), 29-44. doi:10.1002/hrm.20407

Juhdi, N., Pa'wan, F., Hansaram, R. M., Kaur, S., \& Othman, N. A. (2011) HR practices, organizational commitment and turnover intention: $A$ study on employees in Klang Valley, Malaysia. In III World Multiconference on Applied Economics, Business and Development (AEBD '11) (pp. 30-36). Recent Researches in Applied Economics: Iasi, Romania.

Kirschenbaum, S. S. (1992). Influence of experience on information-gathering strategies. Journal of Applied Psychology, 77(3), 343. doi:10.1037/0021-9010.77.3.343
Kraft, K. (1991). The incentive effects of dismissals, efficiency wages, piece-rates and profit-sharing. The Review of Economics and Statistics, 73(3), 451-459. doi:10.2307/2109569

Krishnan, R., Martin, X., \& Noorderhaven, N. G. (2006). When does trust matter to alliance performance? Academy of Management journal, 49(5), 894-917. doi:10.5465/AMJ.2006.22798171

McDaniel, M. A., Schmidt, F. L., \& Hunter, J E (1988). Job experience correlates of job performance. Journal of Applied Psychology, 73(2), 327330. doi:10.1037/0021-9010.73.2.327

McDonald, P. K., Waterhouse, J. M., \& Kellner, A. (2008). Sacked! Young worker's dismissal and the psychological contract, Proceedings 22nd Conference of the Association of Industrial Relations Academics of Australia and New Zealand (pp. 305-315). Melbourne, Australia.

Meyer, J. P., Bobocel, D. R., \& Allen, N. J. (1991). Development of organizational commitment during the first year of employment: A longitudinal study of pre-and post-entry influences. Journal of Management, 17(4), 717-733. doi:10.1177/014920639101700406

Mintzberg, H., Raisinghani, D., \& Théorêt, A. (1976). The structure of "unstructured" decision processes. Administrative Science Quarterly, 21(2), 246-275. doi:10.2307/2392045

Morgeson, F. P., Reider, M. H., \& Campion, M. A. (2005). Selecting individuals in team settings: The importance of social skills, personality characteristics, and teamwork knowledge. Personnel Psychology, 58(3), 583-611. doi:10.1111/j.1744-6570.2005.655.x

Moser, K., \& Kraft, A. (2008). Eskalierendes Commitment gegenüber Mitarbeitern: EinRahmenmodell. Gruppendynamik und Organisationsberatung, 39(1), 106-125.

Nutt, P. C. (2011). Making decision-making research matter: Some issues and remedies. Management Research Review, 34(1), 5-16. doi:10.1108/01409171111096441

Ohana, M., \& Meyer, M. (2010). Should I stay or should I go now? Investigating the intention to quit of the permanent staff in social enterprises. European Management Journal, 28(6), 441-454. doi:10.1016/j. emj.2010.06.007

Østhus, S., \& Mastekaasa, A. (2010). The impact of downsizing on remaining workers' sickness absence. Social Science \& Medicine, 71 (8), 1455-1462. doi:10.1016/j.socscimed.2010.06.045

Quiñones, M. A., Ford, J. K., \& Teachout, M. S. (1995). The relationship between work experience and job performance: A conceptual and meta-analytic review. Personnel Psychology, 48(4), 887-910. doi:10.1111/j.1744-6570.1995.tb01785.X

Saaty, T. L. (2006). Rank from comparisons and from ratings in the analytic hierarchy/network processes. European Journal of Operational Research, 168(2), 557-570. doi:10.1016/j.ejor.2004.04.032

Saaty, T. L. (2008). Decision-making with the analytic hierarchy process. International Journal of Services Sciences, 1(1), 83-98. doi10.1504/ IJSSci.2008.01759

Shah, P. P. (2000). Network destruction: The structural implications of downsizing. Academy of Management Journal, 43(1), 101-112.

Simon, H. (1997). Administrative behavior: A study of decision making processes in administrative organizations. New York, NY: The Free Press.

Stumpf, S. A., \& Dawley, P. K. (1981). Predicting voluntary and involuntary turnover using absenteeism and performance indices. Academy of Management Journal, 24(1), 148-163. doi:10.2307/255830 
Tonelli, M. J. (2000). Demissão: Causas, efeitos e alternativas para em presa e indivíduo. [Review of the book Demissão: Causas, efeitos e alternativas para empresa e indivíduo, of M. P. Caldas]. RAE-Revista de Administração de Empresas, 40(4), 103-108.

Tsai, C. F., \& Yen, Y. F. (2008). A model to explore the mystery between organizations' downsizing strategies and firm performance: Integrating the perspectives of organizational change, strategy and strategic human resource management. Journal of Organizational Change Management, 21(3), 367-384. doi:10.1108/09534810810874831

Tylcsak, L. (1991). Downsizing without disaster: A thoughtful approach to planned workforce reduction. Los Altos, CA: Crisp Publications.

Tzafrir, S. S., \& Dolan, L. S. (2004). Trust ME: A scale for measuring employee manager trust. Journal of Management Research, 2(2), 117-134.

Tzafrir, S. S., \& Eitam-Meilik, M. (2005). The impact of downsizing on trust and employee practices in high tech firms: A longitudinal analysis. The Journal of High Technology Management Research, 16(2), 193-207. doi:10.1016/j.hitech.2005.10.008
Ulrich, D., Younger, J., \& Brockbank, W. (2008). The twenty-first-century HR organization. Human Resource Management, 47(4), 829-850. doi:10.1002/hrm.20247

Uppal, N., Mishra, S. K., \& Vohra, N. (2014). Prior related work experience and job performance: Role of personality. International Journal of Selection and Assessment, 22(1), 39-51. doi:10.1111/ijsa.12055

Watrous, K. M., Huffman, A. H., \& Pritchard, R. D. (2006). When coworkers and managers quit: The effects of turnover and shared values on performance. Journal of Business and Psychology, 21(1), 103-126. doi:10.1007/s10869-005-9021-2

Wiersema, M. (2002). Holes at the top. Why CEO firings backfire. Harvard Business Review, 80(12). Retrieved from https://hbr.org

Williams, C. R., \& Livingstone, L. P. (1994). Another look at the relationship between performance and voluntary turnover. Academy of Management Journal, 37(2), 269-298. doi:10.2307/256830 